\title{
The Effectiveness of Practical Work on Students' Interest towards Learning Physics
}

\author{
Mei Chi Lee* and Fauziah Sulaiman \\ Physics with Electronics Program, Faculty of Science and Natural Resources, Universiti Malaysia Sabah, \\ Malaysia (Email: meichi_maggi@hotmail.com*and fauziahs@ums.edu.my)
}

\begin{abstract}
The purpose of this study is to investigate whether the use of practical work in secondary school can enhance students' interest towards learning physics. This study was conducted in a secondary school at Semporna district in Sabah. A total of sixty-six (66) Form Four students (e.g., 16 years old) participated in this research; thirty-two (32) students were assigned to experimental group and thirty-four (34) students to control group. The experimental group was taught by using practical work meanwhile the control group was taught by using traditional teaching method. Overall, mixed methods were used in this study. Qualitative and quantitative data were collected through questionnaire and interviews. Pre-survey and post-survey on interest towards learning physics were administered before and after the treatment for both groups. Besides, a semi-structured interview was conducted as well after the treatment in both groups to observe about their feedback. Quantitative data were gathered and analysed by using Statistical Package for Social Science (SPSS) Version 22.0. Wilcoxon Signed Ranks Test showed that students in the experimental group showed a significant difference in their interest towards learning physics after the treatment compared to students in control group. Furthermore, the results from the interview were audio-taped and transcribed, indicated that students in experimental group revealed more interest towards learning physics compared to the control group. 4 emerging themes appeared in control group were lack of interest, lack of understanding in physics, lack of excitement and eager to have more experiments and hands-on activities whereas 6 emerging themes identified from experimental group were gain more interest, understanding better in physics, gain new experience, gain excitement, physics made easy and collaboration with friends. Therefore, it is suggested that teacher should conduct practical work with students frequently to increase their interest towards learning physics.
\end{abstract}

Keywords: physics practical work, traditional teaching method, students' interest

\section{Introduction}

In Malaysia, the physics subject is an elective subject where students pursue the subject when they are in upper secondary which is the last two years of their secondary schooling (Curriculum Development Centre, 2005). This is similar to the education system in Kenya (Musasia, Abacha, \& Biyoyo, 2012). Physics curriculum in Malaysia targets to produce active learners among students where they have chances to take part in scientific investigation via hands-on activities and experimentations. Besides, giving students the knowledge and skills in science and technology was one of the purposes in Malaysia physics curriculum. By having this, students will solve problems and make decisions based on scientific attitudes and noble values in everyday life (Curriculum Development Centre, 2005). Physics is always a tough subject to learn (Angell, Guttersrud, Henriksen, \& Isnes, 2004; Fatin, Salleh, Bilal, \& Salmiza, 2012). This will lead to fewer students to take up physics at school and low confidence to study physics (Fatin et al., 2012; Lords, 2006). Based on Dolin's study (as cited in Angell et al., 2004), physics requires students to learn many kinds of representation such as experiments, graphs and mathematical symbols. Another reason that burden students to study physics is that they are not interested in the subject and feel boring (Hirschfeld, 2012). Many factors have contributed to the poor result of physics such as students' poor attitude and no interest towards physics (Josiah, 2013). Students think physics is boring, difficult and irrelevant to daily life (Williams, Stanisstreet, Spall, Boyes, \& Dickson, 2003). Due to this matter, the enrollment of students in science stream was also becoming very low in Malaysia (Salmiza, 2014). For weaker students, they will find physics extremely dull (Yunus \& Ali, 2013) and something exceedingly abstract (Lords, 
2006). Theoretical knowledge is always related to the practical knowledge which assists students to develop their manipulative skills and scientific attitudes (Josiah, 2013). Students' understanding, experience, skills and enjoyment of science will also increase by having practical work. All these will increase students' problemsolving skills and conceptual understanding (Tamir, 1991). Therefore, practical work needs to be reinforced to change students' views towards learning physics. For this reason, the effects of practical work on students' interest towards learning physics are studied.

\section{Literature Review}

Practical work means “...learning experience in which students interact with materials or with secondary sources of data to observe and understand the natural world" (Lunetta, Hofstein, \& Clough, 2007). Students will understand the science concept by conducting experiments in the laboratory (Bruner, 1990). Practical work makes an exceptional learning surrounding that help student to construct their knowledge, enhance logical, inquiry and psychomotor skills (Mashita, Norita, \& Zurida, 2009). Moreover, practical work offers an interactive experience to the students where they can broaden the scope of constructivist learning (Umar, Ubramaniam, \& Ukherjee, 2005). It is believed that by carrying out practical work, students' knowledge can be expanded to understand the real world (Millar, 2004). Teaching objectives can be achieved easily by doing practical work especially in teaching Physics (El-rabadi, 2013). The traditional teaching approach is defined as teaching is entirely depend on textbooks where the teacher teaches the content and students just sit, read, do assignments and taking notes (Ates \& Eryilmaz, 2011). Traditional classes look like a one-person show where usually controlled by direct and one-party instruction (Abida \& Muhammad, 2012). At the same time, students are just unresponsively receiving the information from the teachers (Liu, 2014) and without questioning the teacher (Stofflett, 1999). As a result, students could not form ideas and hard to involve themselves in discovery with building models (Ješková \& Onderová, 2000). Attitudes are the ability to handle with and manage the feelings, and it plays a role in leading human's behaviour during the learning process (Kaya \& Böyük, 2011). Practical work should be well organised and planned earlier to develop positive attitudes (Musasia et al., 2012). Students who gain a positive attitude towards the subject are more likely to be found in students who used practical work in their leaning (Myers \& Fouts, 1992). Practical work teaching strategy influenced on students' attitude and contributed a positive impact on students' mastery of Chemistry concepts when compared to the use of traditional teaching method. Therefore, practical work approach stimulates positive attitudes amongst students for effective learning in science (Okam \& Zakari, 2017).

\section{Research Questions}

(i) Is there any significant difference on students' interest towards learning physics in experimental group?

(ii) Is there any significant difference on students' interest towards learning physics in control group?

\section{Research Methodology}

A quasi-experimental design was used in this study. Both groups were given sixty (60) minutes of equivalent time to carry out the research. All the experiments were conducted in six (6) weeks. Firstly, purposive sampling was employed to select one of the schools from the district. All Form Four students from three (3) science classes of the school were used as the samples for the research. Sixty-six (66) Form Four Science students (i.e., 23 males and 43 females) who took physics subject in the school were purposively selected. Moreover, stratified sampling technique was used to divide the respondents into the control group and experimental group (Gambari, Obielodan, \& Kawu, 2017). Thus, thirty-two (32) students (i.e., 12 males and 20 females) were assigned to the experimental group, and thirty-four (34) students (i.e., 11 males and 23 females) were in control group based on their ability levels. Before practical work is implemented, the pre-survey questionnaire was used to measure students' interest towards learning physics for both groups. There were eleven (11) statements with a combination of positive and negative statements of interest towards learning physics. The 5-point Likert scale was coded as 1, 2, 3, 4, and 5 according to the responses of strongly disagree, disagree, neutral, agree and strongly agree. Example statements are given in Table I. 
TABLE I: Example Statements in the Questionnaire

\begin{tabular}{|c|l|c|l|}
\hline No. & \multicolumn{1}{|c|}{ Statements } & \multicolumn{1}{|c|}{ No. } & \multicolumn{1}{|c|}{ Statements } \\
\hline 1. & Physics class is fun. & 7. & I like to learn Physics. \\
\hline 2. & Physics is more interesting than other science subjects. & 8. & I would like the teaching period of Physics lesson more often. \\
\hline 3. & $\begin{array}{l}\text { Studying Physics is an enjoyable and self-satisfying } \\
\text { experience. }\end{array}$ & 9. & I think learning Physics are unnecessary.* \\
\hline 4. & $\begin{array}{l}\text { The main reason I work hard in Physics because I learn } \\
\text { new things. }\end{array}$ & 10. & I hate to learn Physics.* \\
\hline 5. & Physics lessons are exciting. & 11. & I would like to have fewer Physics topics in the lessons.* \\
\hline 6. & $\begin{array}{l}\text { The only reason I am taking Physics subject is because I } \\
\text { am obligated to do so.* }\end{array}$ & \\
\hline
\end{tabular}

Due to students' English proficiency were low, the researcher translated all the questions into Malay Language and verified by a qualified English Teacher. For the reliability, the questionnaire was piloted on thirtyeight (38) Form 4 students from other schools to assess suitability and clarity of the questions. The Cronbach's Alpha $(\alpha)$ Coefficient obtained was 0.873 after reverse scoring of negative statements. The students from both groups were given the questionnaire again as post-survey after the treatment for 6 weeks. Pre-survey and postsurvey were then analysed using SPSS Version 22.0. Wilcoxon Ranks Signed Test was used to determine the effects of practical work on students' interest towards learning physics. Besides, eight (8) students (i.e., 4 boys 4 girls) were randomly selected in each experimental and control group to have interview session. An open-ended question was adapted from Basheer, Hugerat, Kortam, \& Hofstein (2017). The interview responses were transcribed, and Table II showed the open-ended question asked in experimental and control group.

TABLE II: Open-Ended Question

\begin{tabular}{|l|l|}
\hline \multicolumn{1}{|c|}{ Group } & \multicolumn{1}{c|}{ Interview Question } \\
\hline Experimental Group & How and to what extent has the practical work influenced your interest in Physics? What is your feeling? \\
\hline Control Group & $\begin{array}{l}\text { How and to what extent has the traditional teaching method influenced your interest in Physics? What is } \\
\text { your feeling? }\end{array}$ \\
\hline
\end{tabular}

\section{Results and Discussion}

Wilcoxon signed ranks test results in Table III showed students in the experimental group have a significant difference in the median value Likert scale degree of agreement for post-survey and pre-survey $(Z=-2.71, p=$ $0.01^{*}, p \leq 0.05$ ) whereby the median value for post-survey was 4.47 and pre-survey was 4.19 . However, students in control group showed no significant difference between the median value Likert scale degree of agreement for post-survey and pre-survey $(Z=-0.30, p=0.77, p \geq 0.05)$ whereby the mean value for post-survey was 3.74 and pre-survey was 3.71. The results from the data analysis of students' interest towards learning physics in the experimental group did answer the Research Question No. 1. Therefore, there is a significant difference on students' interest towards learning physics in the experimental group. Besides, the results from the data analysis of students' interest towards learning physics in control group did not answer the Research Question No. 2. There is no significant difference on students' interest towards learning physics in control group.

TABLE III: Results of Students' Interest towards Learning Physics between Control and Experimental Groups

\begin{tabular}{|c|c|c|c|c|}
\hline Group & \multicolumn{2}{|c|}{ Experimental Group (N = 32) } & \multicolumn{2}{c|}{ Control Group (N=34) } \\
\hline \multirow{2}{*}{ Likert Scale Value } & \multicolumn{2}{|c|}{ Wilcoxon Signed Ranks Test } & \multicolumn{2}{c|}{ Wilcoxon Signed Ranks Test } \\
\cline { 2 - 5 } & Pre-survey & Post-survey & Pre-survey & 3.71 \\
\hline Mean & 4.07 & 4.26 & 3.71 & 0.72 \\
\hline SD & 0.39 & 0.42 & 0.66 & 3.74 \\
\hline Median & 4.19 & 4.47 & 3.71 & -0.30 \\
\hline Z / t -value & \multicolumn{2}{|c|}{$-2.71 *$} & & 0.77 \\
\hline p & \multicolumn{2}{|c|}{$0.01^{*}$} & & \\
\hline
\end{tabular}

* is significant at $\mathrm{p} \leq 0.05$

For qualitative data, 4 emerging themes were identified from students' interview in control group which was lack of interest, lack of understanding in physics, lack of excitement and eager to have more experiments and hands-on activities as coded as $C 1, C 2, C 3$ and $C 4$ respectively as shown in Table IV. Below are few direct quotes from students' interview: 
TABLE IV: Emerging Theme with Code in Control Group

\begin{tabular}{|c|c|c|c|c|}
\hline \multicolumn{2}{|l|}{ Code } & & & \\
\hline \multicolumn{2}{|l|}{$\mathrm{C}_{1}$} & & & \\
\hline & Lack of un & & Eager to have more $\mathrm{e}$ \\
\hline$(\mathrm{Ma}$ & & \multicolumn{3}{|c|}{$\begin{array}{l}\text { This traditional teaching method did not affect my interest }{ }_{C l} \text { as this method only talk and write }{ }_{C 3} \text {. For an excellent } \\
\text { student, he or she needs practical }{ }_{C 4} \text { to understand the physics subject more quickly. }\end{array}$} \\
\hline & & \multicolumn{3}{|c|}{$\begin{array}{l}\text { In my opinion, this traditional teaching method taught by teacher did not affect my interest in physics }{ }_{C l} \text { because teacher } \\
\text { only teach and students only listen }{ }_{C 3} \text {. Therefore, students will get bored }{ }_{C 3} \text {. My suggestion is that teacher should have } \\
\text { quizzes to let students be happy and conduct practical }{ }_{C 4} \text { so that they can understand more. }\end{array}$} \\
\hline & & \multicolumn{3}{|c|}{$\begin{array}{l}\text { I disagreed with traditional teaching method because it just talks and listens }{ }_{C 3} \text {. We need to do practicals }{ }_{C 4} \text { so that we can } \\
\text { easily understand physics. So, I am not interested in physics }{ }_{C 1} \text { in such a way because it will affect my thinking about } \\
\text { physics. }\end{array}$} \\
\hline & & \multicolumn{3}{|c|}{$\begin{array}{l}\text { This traditional teaching method did not affect my interest }{ }_{C I} \text {. I felt bored }{ }_{C 3} \text { because talking only and nothing to do during } \\
{ }_{C 3} \text { the lesson. So, I felt bored }{ }_{C 3} \text {. }\end{array}$} \\
\hline 0 & & \multicolumn{3}{|c|}{$\begin{array}{l}\text { Teacher's teaching method made us get bored }{ }_{C 3} \text { and sleepy }{ }_{C 3} \text {. It made me lazy to study. I'm not interested in physics }{ }_{C I} \\
\text { learning because there is no activity. }\end{array}$} \\
\hline 56 & & \multicolumn{3}{|c|}{$\begin{array}{l}\text { I was not satisfied with teacher's teaching method that is a traditional way because it was boring }{ }_{\mathrm{C3}} \text {. If there is activity }{ }_{\mathrm{CA}} \text {, } \\
\text { I won't be feeling bored because we can move around and stay active. Therefore, I am not interested in this learning }{ }_{\mathrm{Cl}} \text {. }\end{array}$} \\
\hline$S 7$ & & \multicolumn{3}{|c|}{$\begin{array}{l}\text { because we just wrote the notes and listened to what the teacher said, no } \\
\text { this subject }{ }_{C l} \text {. }\end{array}$} \\
\hline S & & \multicolumn{3}{|c|}{$\begin{array}{l}\text { I liked traditional teaching methods. However, if it is too long, it makes me feel bored }{ }_{C 3} \text {. There were many things taught } \\
\text { by the teacher and need to remember. This will make me feel confused }{ }_{C 2} \text { about what has been taught. }\end{array}$} \\
\hline
\end{tabular}

Besides, 6 emerging themes were also identified from students' interview in experimental group which was gain more interest, understanding better in physics, gain new experience, gain excitement, physics made easy and collaboration with friends as coded $D 1, D 2, D 3, D 4, D 5$ and $D 6$ respectively as shown in Table V. Below are few direct quotes from students' interview:

TABLE V: Emerging Theme with Code in Experimental Group

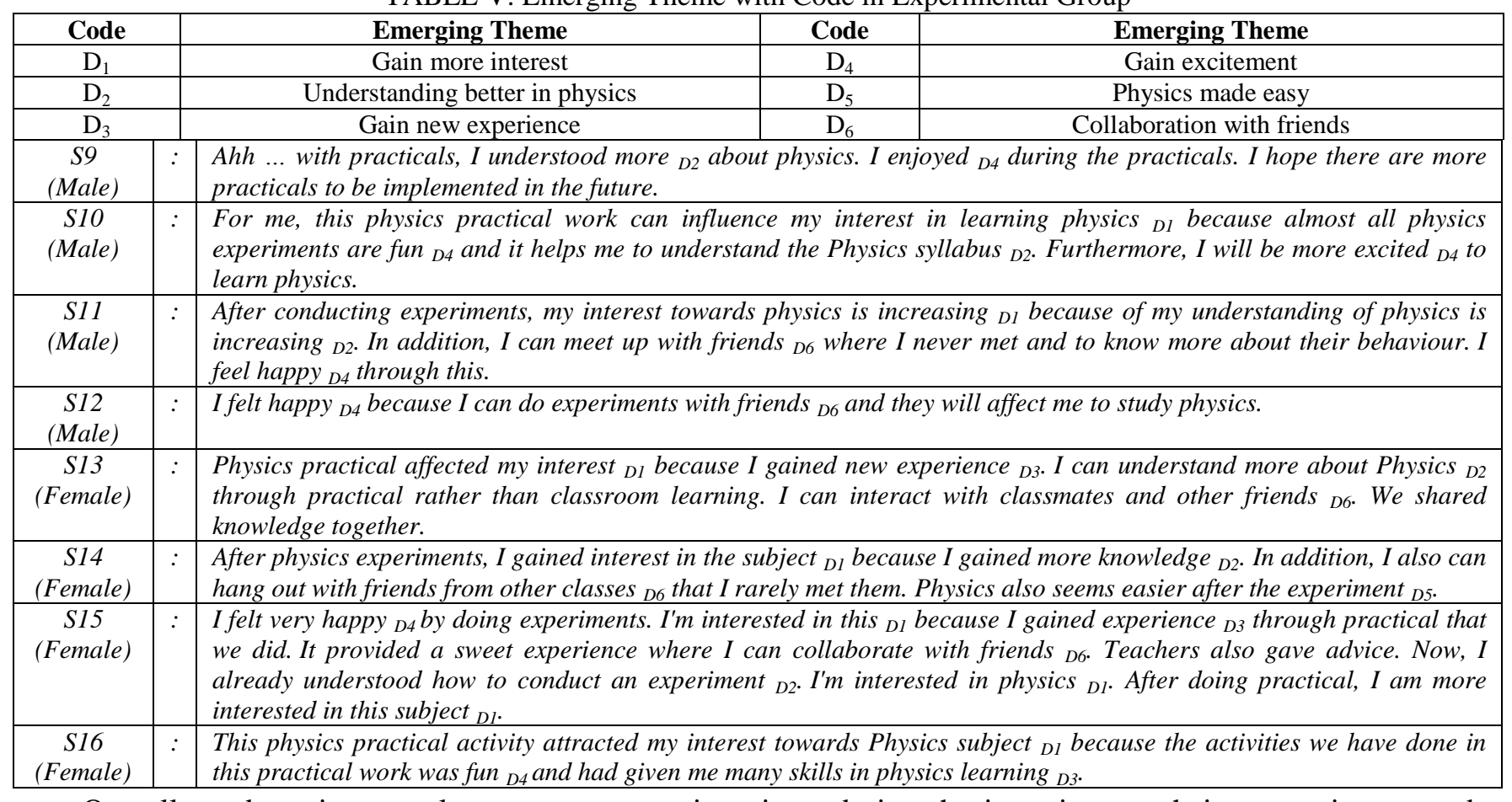

Overall, students in control group gave negative views during the interview on their perception towards traditional teaching method. This method apparently did not affect their interest towards learning physics. They were also unable to understand physics concept because most of them felt boring during the class. Therefore, students were hoping that there will be more experiments and hands-on activities to be carried out in the class. On the other hand, students in experimental group able to give positive views during the interview on their perception towards the implementation of practical work. All students agreed that they gained more interest 
towards learning physics. Besides, they had a better understanding in physics, gained new experience, gained excitement and able to collaborate with friends after having practical work in class.

These findings are similar to previous studies which have been reported by Kibirige \& Tsmago (2013) which stated that laboratory investigation would gradually develop students' behaviours such as positive attitudes, motivation and interest towards learning physics. They reported students who went through practical work would develop positive attitude whereas students who taught by traditional teaching method showed negative attitudes in learning science. Besides, practical work involved tasks that attract students' excitements and raised interest, unlike the traditional teaching method. Students who underwent practical work were excited to see the phenomenon, handle with the apparatus, enjoyed in the science lesson and eventually will build up student's desire to learn science in future. However, the traditional teaching approach could not make students enjoy physical science, and their attitude was negative towards the subject. This may be because of instructive approach were too abstract. Musasia et al. (2012) also found that practical work can develop students' interest towards learning physics and build up students' motivation in learning as well. Students tend to learn effectively in activity-based lessons where they can touch and use the apparatus to increase their understanding towards physics (Kibirige \& Tsamago, 2013; Musasia et al., 2012). Similar findings have been reported by Okam and Zakari (2017), with practical work teaching strategy, it influenced on students' attitude and contributed a positive impact on students' mastery of science concepts when compared to the use of traditional teaching method. Practical work approach stimulates a positive attitude amongst students for effective learning in science. Therefore, practical work should be well organised and planned beforehand by the teacher to develop positive attitudes among students (Musasia et al., 2012). Both quantitative and qualitative results and findings in this study proved that practical work gives positive effects on students' interest towards learning physics.

\section{Conclusion}

The results and findings revealed that if practical work can serve as a useful platform to develop positive effect on students' interest towards learning physics. Practical work helps students in gaining more interest, new experience, excitement, had a better understanding in physics and able to collaborate with friends compared to traditional teaching method which did not increase students' interest towards learning physics. Teachers should conduct practical work at least once a week to develop students' interest towards physics. The Ministry of Education should also give training time to time to the teacher on how to conduct experiments according to the module. With this, teachers' confidence to conduct experiment will be enhanced.

\section{References}

[1] Abida, K., \& Muhammad, A. (2012). Constructivist Vs Traditional: Effective instructional approach in teacher education. International Journal of Humanities and Social Science, 2(5), 170-177.

[2] Angell, C., Guttersrud, Ø., Henriksen, E. K., \& Isnes, A. (2004). Physics: Frightful, but fun - Pupils' and teachers' views of physics and physics teaching. Science Education, 88(5), 683-706. https://doi.org/10.1002/sce.10141

[3] Ates, Ö., \& Eryilmaz, A. (2011). Effectiveness of hands-on and minds-on activities on students' achievement and attitudes towards physics. Asia-Pacific Forum on Science Learning and Teaching, 12(1), 1-22.

[4] Bruner, J. (1990). Acts of Meaning. Cambridge, Massachusetts, London, England: Harvard University Press.

[5] Basheer, A., Hugerat, M., Kortam, N., \& Hofstein, A. (2017). The Effectiveness of Teachers' Use of Demonstrations for Enhancing Students â $€^{\mathrm{TM}}$ Understanding of and Attitudes to Learning the Oxidation-Reduction Concept. Eurasia Journal of Mathematics, Science and Technology Education, 8223(3), 555-570.

[6] Curriculum Development Centre. (2005). Integrated Curriculum for Secondary Schools, Physics Form 4. Retrieved July 25, 2016, from http://www.stsimon.edu.my/mn/wp-content/uploads/2015/05/hsp_physics_f4.pdf

[7] El-rabadi, E. G. S. (2013). The Effect of Laboratory Experiments on the Upper Basic Stage Students Achievement in physics . Journal of Education and Practice, 4(8), 62-71. 
[8] Fatin, A. P., Salleh, A., Bilal, A., \& Salmiza, S. (2012). Faktor penyumbang kepada kemerosotan penyertaan pelajar dalam aliran sains: satu analisis sorotan tesis. Medc2012. https://doi.org/10.14221/ajte.2011v36n3.2

[9] Gambari, A. I., Obielodan, O. ., \& Kawu, H. (2017). Effects of Virtual Laboratory on Achievement Levels and Gender of Secondary School Chemistry Students in Individualized and Collaborative Setting in Minna, Nigeria. The Online Journal of New Horizons in Education, 7(1), 86-102.

[10] Hirschfeld, D. (2012). Interest in science careers wanes in Latin America. Retrieved November 10, 2016, from http://www.scidev.net/global/capacity-building/news/interest-in-science-careers-wanes-in-latin-america.html\#

[11] Ješková, Z., \& Onderová, L. U. (2000). Active Learning in Physical Laboratory. In Second European Conference on Physics Teaching in Engineering Education-PTEE. Hungary, Budapest.

[12] Josiah, M. M. (2013). Effects of Practical Physics Knowledge on Students 'Academic Achievement: A Study of Pankshin Local Government Area of Plateau State, Nigeria. World Educators Forum, 2(1), 1-9.

[13] Kaya, H., \& Böyük, U. (2011). Attitudes Towards Physics Lessons and Physical Experiements of the High School Students. European Journal of Physics Education, 2(1), 16-22.

[14] Kibirige, I., \& Tsamago, H. (2013). Learners' Performance in Physical Sciences Using Laboratory Investigations. International Journal of Educational Sciences, 5(4), 425-432.

[15] Liu, S. (2014). Implementing Project-Based Learning in Physics and Statics Courses. In I121st ASEE Annual Conference \& Exposition (pp. 1-7). Indianapolis, Indiana.

[16] Lords, H. of. (2006). Science Teaching in Schools.

[17] Lunetta, V. N., Hofstein, A., \& Clough, M. P. (2007). Learning and teaching in the school science laboratory: An analysis of research, theory, and practice. Handbook of Research on Science Education, (January 2007), 393-431.

[18] Mashita, A., Norita, M., \& Zurida, H. I. (2009). The effect of an individualized laboratory approach through microscale chemistry experimentation on students' understanding of chemistry concepts, motivation and attitudes. Chemistry Education Research and Practice, 10(December 2015), 53. https://doi.org/10.1039/b901461f

[19] Millar, R. (2004). The role of practical work in the teaching and learning of science. Paper prepared for the Committee: High School Science Laboratories: Role and Vision, National Academy of Sciences, Washington, DC.

[20] Musasia, A. M., Abacha, O. A., \& Biyoyo, M. E. (2012). Effect of Practical Work in Physics on Girls' Performance, Attitude Change and Skills Acquisition in the Form Two-Form Three Secondary Schools'. International Journal of Humanities and Social Science, 2(23), 151-166.

[21] Myers, R. E., \& Fouts, J. T. (1992). A cluster analysis of high school science classroom environments and attitude toward science. Journal of Research in Science Teaching, 29(9), 929-937. https://doi.org/10.1002/tea.3660290904

[22] Okam, C. C., \& Zakari, I. I. (2017). “ Impact of Laboratory-Based Teaching Strategy on Students 'Attitudes and Mastery of Chemistry in Katsina Metropolis ”, Katsina State, Nigeria. International Journal of Innovative Research and Development, 6(1), 112-121.

[23] Salmiza, S. (2014). Malaysian students' motivation towards Physics learning. European Journal of Science and Mathematics Education, 2(4), 223-232.

[24] Stofflett, R. T. (1999). Putting Constructivist Teaching into Practice in Undergraduate Introductory Science. Electronic Journal of Science Education, 3(2), 1-12.

[25] Umar, P. R. K., Ubramaniam, T. S., \& Ukherjee, T. K. M. (2005). Issues in Physics Practicals in an Open and Distance Learning Environment. Asian Journal of Distance Education, 3(1).

[26] Williams, C., Stanisstreet, M., Spall, K., Boyes, E., \& Dickson, D. (2003). Why aren't secondary students interested in physics? IOP Publishing Ltd., 38(4), 324-329.

[27] Yunus, F. W., \& Ali, Z. M. (2013). Attitude towards Learning Chemistry among Secondary School Students in Malaysia. Journal of Asian Behavioural Studies, 3(11), 1-11. 